\title{
Analisis Kestabilan Sistem Sulselbar Akibat Dinamik Load Menggunakan Metode Operation Rescheduling
}

\author{
Indar Chaerah Gunadin $^{* 1}$, Zaenab ${ }^{1}$, M. Jibral Agung ${ }^{1}$, Anwarriska Apriana $^{1}$, Agus Siswanto ${ }^{2}$ \\ ${ }^{1}$ Jurusan Teknik Elektro, Fakultas Teknik, Universitas Hasanuddin \\ Jl. Perintis Kemerdekaan Km. 10 Tamalanrea - Makassar, 90245 \\ ${ }^{2}$ Teknik Elektro, Fakultas Teknik, Universitas 17 Agustus 1945, Cirebon \\ J1. Perjuangan No. 17, Kota Cirebon \\ *Email: indarcg@gmail.com
}

DOI: 10.25042/jpe.052018.05

\begin{abstract}
Abstrak
Penjadwalan pembebanan merupakan hal penting untuk mengoptimalkan transmisi daya pada sistem. Cara untuk menghasilkan sistem transmisi energy listrik stabil adalah dengan meminimalkan rugi-rugi sistem transmisi (transmission losses) menggunakan antara momen inertia dan daya pada generator pembangkit. Gangguan pembangkitan merupakan gambaran rugi-rugi daya pada saluran transmisi yang dihasilkan saat pembangkit mengirim daya kebeban. Mentransfer daya dari pembangkit yang losses tinggi ke pembangkit yang losses rendah. Rescheduling System dapat meminimalkan rugi-rugi sistem transmisi. Pada penelitian ini hasil penjadwalan metode ini dibandingkan dengan hasil realisasi penjadwalan pembangkit-pembangkit termal dari Pusat Penyaluran dan Pengatur Beban (P3B) PT PLN (Persero) Sulselbar. Perbandingan ini bertujuan untuk membuktikan metode ini lebih baik dari penjadwalan yang direalisasi PLN, sehingga ditemukan pula keunggulan dan kelemahan metode. Setelah dilakukan penelitian, metode ini menghasilkan daya pembangkitan yang mendekati kestabilan, karena besarnya daya yang dihasilkan mendekati daya pembangkitan PLN dalam memenuhi permintaan beban yang sama tetapid engan rugi-rugi transmisi yang lebih kecil dan biaya bahan bakar yang lebih murah. Hasil pembebanan stabilakan menghasilkan efisiensi perusahaan listrik sehingga dapat menekan biaya operasional pembangkitan dan tentunya secara tidak langsung berdampak pada murah biaya produksi listrik.
\end{abstract}

\section{Abstract}

Stability Analysis of Sulselbar System due to Dynamic Load using Operation Rescheduling Method. Load scheduling is essential for optimizing power transmission on the system. The way to produce a stable electrical energy transmission system is to minimize transmission losses using between the moment of inertia and power on the generator. The generation noise is a description of the power losses on the transmission line generated when the power plant sends the load power. Transferring power from a high losses plant to a low losses plant. Rescheduling System can minimize transmission system losses. In this research, the scheduling result of this method is compared with the realization of scheduling of thermal generators from PT PLN (Persero) Sulselbar Central Disbursement and Control Center (P3B). This comparison aims to prove this method better than scheduling realized PLN, so that found also advantages and disadvantages method. After the research, this method produces a generation power that is close to stability, because the amount of power generated close to the power generation of PLN in fulfilling the same load demand remains with smaller transmission losses and cheaper fuel costs. The result of stable loading results in the efficiency of the electricity company so that it can reduce the operational cost of the generation and of course indirectly impact on the low cost of electricity production.

Kata Kunci: Dinamik load, PSAT, MATLAB, rescheduling system, stabilitas

\section{Pendahuluan}

Pada masa modern seperti sekarang ini, Indonesia negara yang memiliki jumlah populasi penduduk besar dan perkembangan industri mengalami peningkatan dan memiliki tingkat kebutuhan sumber energi listrik yang besar pula. Terutama di negara berkembang seperti
Indonesia, biaya bahan bakar merupakan faktor utama dalam perencanaan, pengoperasian, dan pengontrolan sistem tenaga listrik. Kebutuhan energi listrik terus bertambah, maka dibutuhkan sistem tenaga listrik dengan beberapa pembangkit listrik saling interkoneksi untuk dapat memenuhi kebutuhan beban tersebut [1-2]. 
Dalam pengoperasian sistem tenaga listrik yang terdiri dari beberapa pusat pembangkit listik, diperlukan suatu koordinasi di dalam penjadwalan besar daya listrik dibangkitkan masing-masing pusat pembangkit agar didapatkan suatu pembebanan optimal dan lebih ekonomis [3]. Hal ini berarti dalam pembangkitan dan penyaluran energi itu harus dilakukan secara ekonomis dan rasional.

Stabilitas sistem tenaga listrik merupakan karakteristik sistem tenaga memungkinkan mesin bergerak serempak dalam sistem pada operasi normal dan dapat kembali dalam keadaan seimbang setelah terjadi gangguan. Secara umum permasalahan stabilitas sistem tenaga listrik terkait dengan kestabilan sudut rotor (Rotor Angle Stability) dan kestabilan tegangan (Voltage Stability). Berdasarkan rentang waktu dan mekanisme terjadi ketidakstabilan. Kestabilan sudut rotor di klasifikasikan menjadi Small Signal Stability dan Transient Stability. Small Signal Stability adalah kestabilan sistem untuk gangguan-gangguan kecil dalam bentuk osilasi elektromekanik yang tak teredam, sedangkan transient Stability dikarenakan kurang sinkron torsi dan diawali oleh gangguan-gangguan besar [4].

Dalam pengoperasian pembebanan jaringan sulselbar dilakukan dengan pembagian pembebanan pada pembangkit tenaga listrik (penjadwalan pembebanan) menyuplai beban. Dalam pembagian pembebanan ini kerap kali mengabaikan rugi-rugi pada sistem transmisi. Rugi-rugi pada sistem transmisi (losses) menyebabkan sistem transmisi jaringan sulselbar menjadi kurang sehingga PT. PLN merencanakan pengembangan jaringan [5].

Untuk mendapatkan sistem transmisi seimbang maka perhitungan momen inertia dan daya pada generator pembangkit sangat diperlukan. Perhitugan ini mengetahui pembangkit menyebabkan losses tinggi dan pembangkit menyebabkan losses rendah dengan membandingkan dua buah pembangkit. Penjadwalan pembebanan dengan rugi saluran transmisi rendah dapat menekan nilai rugi-rugi sistem transmisi. Salah satu teknik solusi untuk penjadwalan pembebanan adalah dengan menggunakan Power
System Analisys Toolbox (PSAT). PSAT menyediakan berbagai jenis model komponen statis dan dinamik yang semua dapat dijalankan dengan garfik interface (GUI) sehingga memudahkan dalam penggunaanya serta tersedia simulink yang memudahkan dalam mendesain jaringan.

\section{Stabilitas Sistem Tenaga Listrik}

Sistem tenaga listrik umum terdiri dari beberapa pembangkit (sistem multi mesin) yang terhubung secara interkoneksi melalui jaringan Transmisi. Tujuan interkoneksi sistem adalah untuk menjamin kelangsungan pasokan daya listrik ke beban. Stabilitas sudut rotor merupakan hal yang sangat vital dalam sistem tenaga listrik, karena berkaitan dengan keandalan dan keamanan sistem, oleh karena itu harus menjadi pertimbangan utama dalam perencanaan maupun pengoperasian. Sistem tenaga listrik modern memiliki banyak peralatan dinamik yang bervariasi, misalnya mesin-mesin sinkron dan beban yang secara terus-menerus rentan terhadap gangguan eksternal maupun internal.

Dalam kondisi demikian sering terjadi osilasi tiap bagian maupun antar bagian pada sistem tenaga listrik sedang terinterkoneksi. Sistem tenaga listrik yang beroperasi dalam keadaan stabil, memiliki keseimbangan antara daya input mekanis (prime-mover) dengan daya output listrik. Dalam keadaan ini semua generator berputar dalam kecepatan sinkron, setiap kenaikan atau penurunan beban diikuti dengan perubahan daya mekanis prime-mover generator.

Bila daya mekanis tidak dapat menyesuaikan dengan daya beban dan rugi-rugi sistem, maka kecepatan rotor generator dan tegangan akan menyimpang dari keadaan normal. Stabilitas sistem tenaga listrik dapat didefinisikan sebagai kemampuan suatu sistem tenaga listrik atau komponennya untuk mempertahankan sinkronisasi dan keseimbangan sistem[6]. Pada keadaan operasional stabil dari system tenaga listrik, terdapat keseimbangan antara daya input mekanis pada penggerak mula dengan daya output listrik pada sistem.

Peningkatan dinamik terhadap pemakaian maupun pelepasan secara simultan kebutuhan 
daya reaktif beban sistem dalam rating daya yang besar (heavy loading) menyebabkan fluktuasi tegangan dan frekuensi sistem, jika fluktuasi tegangan melewati batas toleransi nilai tegangan yang ditetapkan yakni $+5 \%$ dan $-10 \%$ dapat mempengaruhi kestabilan tegangan sistem.

Permasalahan utama yang terjadi di sistem tenaga adalah operasi sinkron antara tegangan, frekuensi, dan sudut fasa. Operasi ini akan menyatakan keserempakan kerja mesin-mesin sinkron di jaringan dalam rentang waktu tertentu. Dalam jaringan tenaga listrik sistem interkoneksi merupakan hal yang umum dijumpai karena pemanfaatan interkoneksi di jaringan akan meningkatkan keandalan dan dapat memperbesar suplai daya yang dihasilkan. Namun, permasalahan yang mungkin muncul pada sistem interkoneksi adalah tidak seimbangnya tegangan, frekuensi, dan sudut fasa, sehingga sistem tenaga listrik tidak dapat berjalan serempak atau mengalami ketidakstabilan[7-10].

Sistem tenaga listrik yang baik adalah sistem tenaga yang dapat melayani beban secara kontinyu dengan tegangan dan frekuensi yang konstan.Fluktuasi tegangan dan frekuensi yang terjadi harus berada pada batas toleransi yang diizinkan agar peralatan listrik konsumen dapat bekerja dengan baik dan aman.Kondisi sistem yang benar-benar mantap sebenarnya tidak pernah ada.Perubahan beban selalu terjadi dalam sistem. Penyesuaian oleh pembangkit akan dilakukan melalui gevernor dari penggerak mula daneksitasi generator.

Perubahan kondisi sistem yang seketika, biasanya terjadi akibat adanya gangguan hubung singkat pada sistem tenaga listrik, dan pelepasan atau penambahan beban yang benar secara tibatiba. Akibat adanya perubahan kondisi kerja dari sistem ini, maka keadaan sistem akan berubah dari keadaan lama ke keadaan baru. Periode singkat di antara kedua keadaan tersebut disebut periode paralihan atau transient.Oleh karena itu diperlukan suatu analisis sistem tenaga listrik untuk menentukan apakah sistem tersebut stabil atau tidak, jika terjadi gangguan.Stabilitas transient didasarkan pada kondisi kestabilan ayunan pertama (first swing) dengan periode waktu penyelidikan pada detik pertama terjadi gangguan[11-13].

Salah satu metode yang dapat digunakan untuk menentukan kestabilan suatu sistem tenaga listrik apabila mengalami gangguan adalah metode kriteriasama luas. Walaupun metode ini tidak dapat dipergunakan untuk sistem multimesin namun sangatlah membantu untuk memahami faktor-faktor dasar yang mempengaruhi stabilitas transient sistem tenaga listrik.

Metode kriteria sama luas (Equal Area Criterion, EAC) merupakan contoh metode langsung untuk memperoleh waktu pemutusan kritis (Critical Clearing time), yang mana hanya terbatas untuk satu mesin saja dengan bus infinite (Singgle Machine Infinite Bus, SMIB). Kurva ayunan merupakan alat elevasi suatu kestabilan sistem yang digunakan kestabilan-kestabilan transient sistem tenaga lisrik.

Alat bantu dalam studi analisa sistem tenaga listrik adalah komputer, karena peranan komputer dalam Analisis Sistem Tenaga mempunyai keuntungan diantara fleksibel (dapat digunakan untuk menganalisis hampir semua persoalan), teliti, cepat dan ekonomis. Software komputer yang digunakan adalah Matlab, karena Matlab merupakan bahasa canggih untuk komputasi teknik. Matlab merupakan integrasi dari komputasi, visualisasi dan pemrograman dalam suatu lingkungan yang mudah digunakan, karena permasalahan dan pemecahannya dinyatakan dalam notasi matematika biasa.

Sistem tenaga merupakan sistem sangat kompleks dan terdiri dari banyak peralatan listrik yang memiliki karakteristrik serta tanggapan masing-masing terhadap perubahan kondisi. Sistem tenaga listrik mempunyai variasi beban yang sangat dinamis dan akan berubah-ubah setiap detiknya. Perubahan beban yang tidak terduga dapat dikategorikan sebagai gangguan yang mengakibatkan ketidakseimbangan antara pasokan listrik dan permintaan energi listrik. Perubahan tersebut mengharuskan setiap pembangkit menyesuaikan daya keluaran melalui kendali governor maupuneksitassi mengikuti perubahan beban. Jika hal ini tidak dilakukan maka akan menyebabkan keseimbangan daya dalam sistem terganggu dan efisiensi 
pengoperasian sistem menurun menyebabkan kinerja sistem memburuk.

Stabilitas sistem tenaga listrik merupakan karakteristik sistem tenaga yang memungkinkan mesin bergerak serempak dalam sistem pada operasi normal dan dapat kembali dalam keadaan seimbang setelah terjadi gangguan. Secara umum permasalahan stabilitas sistem tenaga listrik terkait dengan kestabilan sudut rotor (Rotor Angle Stability) dan kestabilan tegangan (Voltage Stability) [11-12].

Klasifikasi ini berdasarkan rentang waktu dan mekanisme terjadinya ketidakstabilan. Kestabilan sudut rotor di klasifikasikan menjadi Small Signal Stability dan Transient Stability. Small Signal Stability adalah kestabilan sistem untuk gangguan-gangguan kecil dalam bentuk osilasi elektromekanik yang tak teredam, sedangkan transient Stability dikarenakan kurang sinkronnya torsi dan diawali dengan gangguan gangguan besar. Masalah kestabilan biasanya diklasifikasikan menjadi tiga tipe bergantung pada sifat alami dan magnitude gangguan antara lain stabilitas steady state, transient, dan dinamis [14].

\subsection{Penjadwalan Sistem (System Rescheduling)}

Keputusan Rescheduling (Penjadwalan Ulang) menunjukkan langkah terakhir dalam siklus produksi. Proses produksi dimulai dengan capacity planning (langkah 1), diikiuti dengan aggregate planning (langkah 2), dan diakhiri dengan operations scheduling (langkah 3). Fungsi utama dari penjadwalan adalah untuk mengembangkan tugas kerja khusus dan untuk mengorganisir waktunya. Master Schedule (Jadwal Induk) sering di pergunakan sebagai input dasar untuk proses penjadwalan operasi. Tujuan dasar dari proseses penjadwalan ulang (Rescheduling System) adalah merancang urutan kerja optimal (yaitu, rencana yang menunjukkan trade off (pertukaran) terbaik diantara konflik tujuan.

Urutan waktu pekerjaan sering di rumuskan menggunakan aturan keputusan perioritas. Secara spesifik, aturan keputusan perioritas digunakan untuk menentukan pekerjaan diproses ketika sejumlah pekerjaan sedang menunggu. Ke efektifan relatif dari tiap aturan dapat ditentukan dengan mengamati kinerja dari sistem.

\subsection{Continuation Power Flow (CPF)}

Salah satu aplikasi penting dari studi aliran daya adalah untuk melacak dan memprediksi respon sistem untuk menjamin tegangan pada sistem tidakcollapse keandalan, dan pengendalian distribusi energi listrik. Evaluasi Power-Voltage atau kurva karakteristik "PV", ditunjukkan pada Gambar 1. memberikan informasi penting, yaitu stabilitas tegangan dan kemampuan batas beban, pada kondisi steady state.

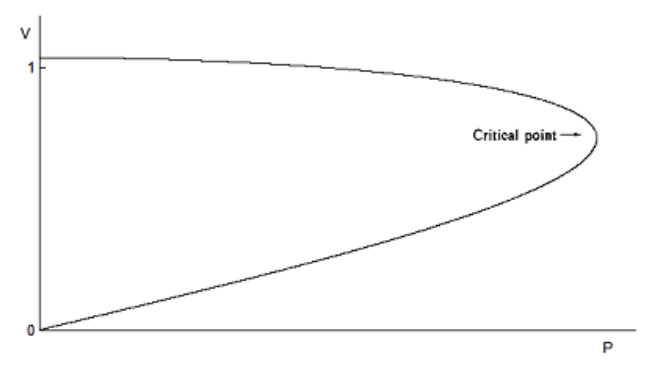

Gambar 1. Kurva PV

Di ujung kurva, di mana sistem mencapai titik kritis dari operasi, pada keadaan normal tidak dapat lagi memenuhi permintaan daya reaktif. Dengan demikian, kurva atas merupakan operasi yang stabil, sedangkan kurva bawah adalah wilayah yang tidak stabil.

Metode CPF dilakukan dengan reformulasi persaman aliran daya melalui penambahan parameter pembebanan, yang diekspresikan sebagai berikut:

$$
F(\theta, V)=\lambda K
$$

Dimana :

$\theta$ : vector dari sudut tegagan bus

$V$ : vector dari besar tegangan bus

$\lambda$ : parameter beban

$K$ : vector yang menggambarkan persentase perubahan beban pada tiap bus

Persamaan (1) merupakan persamaan non linear dengan spesifikasi $0 \leq \lambda \leq \lambda$ critical. Dengan $\lambda=0$ adalah kondisi pembebanan awal, dan $\lambda=$ גcritical. Saat kondisi pembebann kritis. Persamaan (1) dapat ditulis kembeli sehinggga menghasilkan 


$$
F(\theta, V, \lambda)=0
$$

Pada predictor step, pendekatan liniear digunakan untuk menghitung solusi dengan perubahan dari salah satu state variable $(\theta, V, \lambda)$ dari Persaman (2), dapat ditulis persamaan linearnya

$$
F_{\theta} d \theta+F_{v} d V+F_{\lambda} d \lambda=0
$$

Atau

$$
\left[F_{\theta} F_{v} F_{\lambda}\right]\left[\begin{array}{l}
d \theta \\
d V \\
d \lambda
\end{array}\right]=0
$$

Dengan penambahan $\lambda$ pada persamaan aliaran daya akan menimbulkan suatu variabel yang tidak diketahui maka perlu penambahan satu lagi persamaan untuk menemukan solusinya. Tangan vector yang bernilai 1 atau -1 akan ditambahkan, parameter ini sering disebut dengan continuation parameter. Persamaan (3) menjadi

$$
\left[\frac{F_{\theta} F_{v} F_{\lambda}}{e k}\right]\left[\begin{array}{l}
d \theta \\
d V \\
d \lambda
\end{array}\right]=\left[\begin{array}{c}
0 \\
1 \\
-1
\end{array}\right]
$$

Pada Persamaan (4) di mana $e k$, merupakan vektor baris dengan semua elemen sama dengan no keculai untuk ke $k^{\text {th }}$ yang bernilai 1 . Ketika tangent vector telah didapat, predeksi untuk solusi selanjutnya dituliskan seperti dibawah ini

$$
\left[\begin{array}{l}
\theta \\
V \\
\lambda
\end{array}\right]=\left[\begin{array}{l}
\theta_{0} \\
V_{0} \\
\lambda_{0}
\end{array}\right]+\sigma\left[\begin{array}{l}
d \theta \\
d V \\
d \lambda
\end{array}\right]
$$

Dengan penanda " 0 " adalah nilai dari state variabel saat memulai predicator step.Pada corrector step, persamaan $F(\theta, V, \lambda)=0$ diberi tambahan satau persamaan untuk state variable sebagai continuation parameter. Maka didapatkan persamaan baru.

$$
\left[\frac{F(\theta, V, \lambda)}{x_{k}-\eta}\right]=[0]
$$

Pada Persamaan (6), $x_{k}$ adalah state variable yang dipilih sebagai continuation parameter dan $\eta$ bernilai sama dengan $x_{k}$ yang diprediksi. Adanya $x_{k}$ membuat jacobian tidak singular pada titik kritis operasi, sehingga analisis CPF dapat di lanjutkan.

\section{Hasil Penelitian}

Dalam simulasi Rescheduling pada jaringan sulselbar, menampilkan simulasi besaran nilai pada setiap bus dan data transmisinya, yang di tunjukkan melalui tabel pada Power Flow dan Line Flow, nilai ini menunjukan besaran daya tiap pembangkit yang di gunakan. Perhitungan aliran daya diperlukan untuk mengetahui kondisi normal suatu sistem tenaga.

3.1. Simulasi PSAT Keadaan Normal pada Batas 275 kV PLTA Poso

Gambar 2, memperlihatkan kondisi normal rangkaian simulasi Sulselbar dalam keadaan stabil dengn bantuan simulasi pada Matlab menggunakan PSAT.

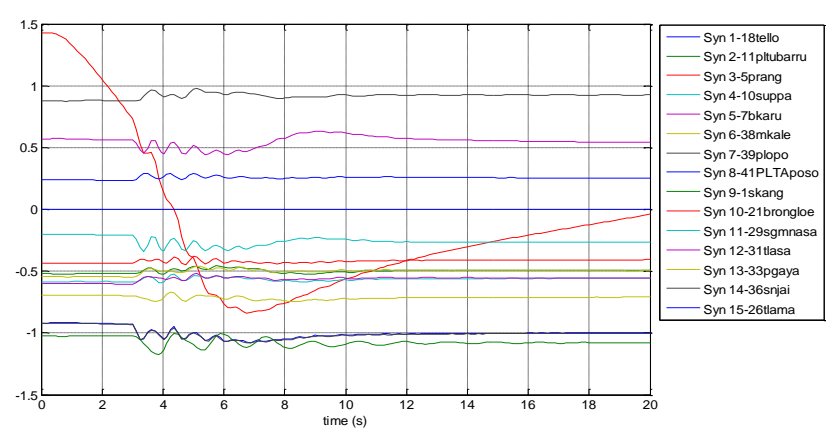

Gambar 2. Kurva normal dengan reference angle $275 \mathrm{kV}$

\subsection{Simulasi PSAT Keadaan Gangguan pada} Batas 275 kV PLTA Poso

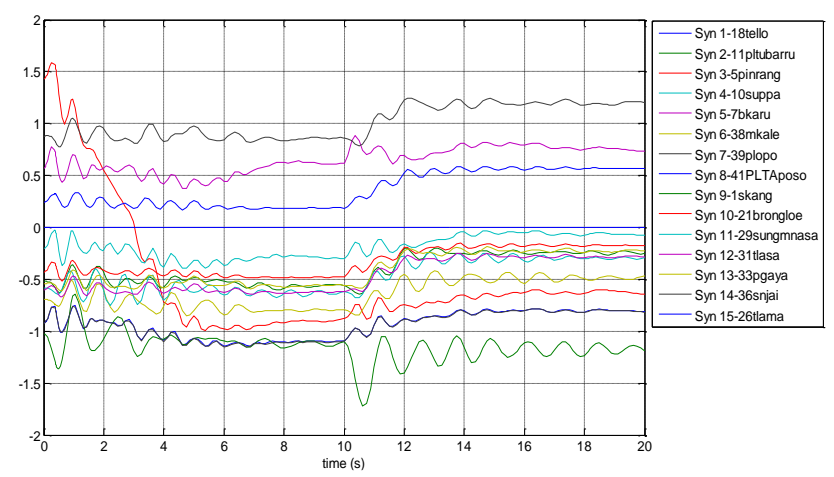

Gambar 3. Kurva gangguan dengan reference angle $275 \mathrm{kV}$ 
Keadaan gangguan pada rangkaian simulasi sulselbar di berikan trouble hubung singkat bus 15 TNASA, sehingga menghasilkan Gambar 3 grafik yang bergelombang dari 15 pembangkit yang ada melalui simulasi PSAT.

\subsection{Simulasi PSAT Keadaan Rescheduling pada Batas 275 kV PLTA Poso}

Proses rescheduling (penjadwalan ulang) berdasarkan simuasi gangguan pada Gambar 4, daya pada momen inertia P.gen (resch) di gunakan untuk menschedule ulang pada gambar rangkaian di Matlab. Dalam artian nilai P.gen $(\mathrm{kV})$ di ubah menjadi P.gen (resch) sesuai data pada (tabel 4.7 identitas generator pembangkit), dalam perubahan nilai tersebut memperlihatkan grafik resheduling

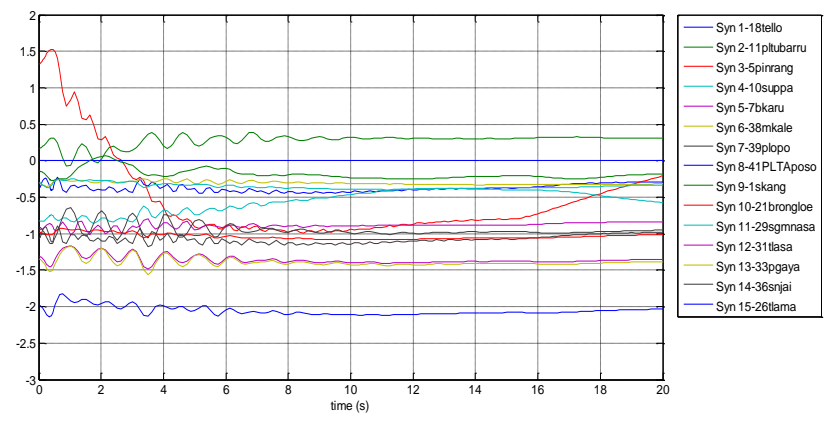

gambar 4. kurva rescheduling dengan reference angle $275 \mathrm{Kv}$

\subsection{Analisis Grafik Simulasi Gangguan- Rescheduling 275 kV}

Percobaan simulasi ini mencoba untuk memberikan gangguan pada salah satu pembangkit untuk mengetahui sejauh mana perbedaan grafik yang muncul dan pada saat di Reschedule, di sini kami mencoba mensimulasikan dari 3 pembangkit yang berbeda yang masing di proses saat gangguan dan Reschedule.

\subsection{Pembangkit 21 Brongloe}

Dalam mensimulasikan proses gangguan pada salah satu generator di SulSelBar (15 Tonasa), terlihat adanya garis grafik yang menonjol pada 21 Brongloe yang di beri tanda garis merah, hal ini menunjukkan adanya ketidakstabilan dalam peralatan. Tetapi kemudian setelah Di Rescheduling maka ada perubahan grafik di tandai oleh garis biru, ini menunjukkan keadaan yang mendekati batas Normal.

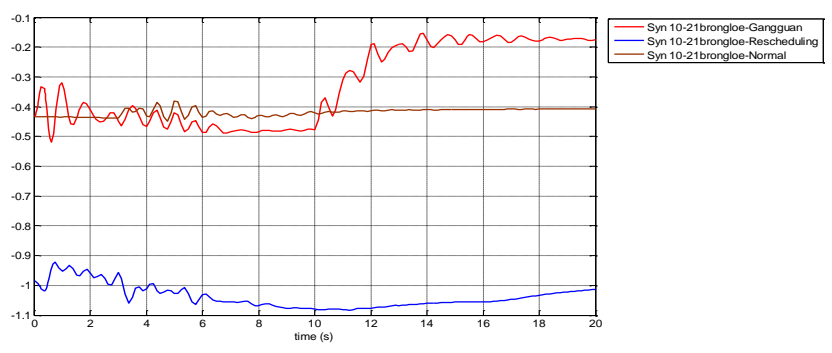

Gambar 5. Kurva gangguan dan rescheduling pada pembangkit 21 Brongloe

\subsection{Pembangkit 11 PLTU Barru}

Pada simulasi pembangkit 11 pltubarru ini, ada tiga keadaan yaitu: normal, gangguan dan Rescheduling, dalam keadaan gangguan terlihat grafik sangat menonjol memperlihat keadaan tidak stabil hal ini di pengaruhi dari kestabilansistem yang takteredam, melalui kestabilan tegangan (voltage stabililty), Pada tiap daya generator dapat mengurangi gangguan kestabilan peralatan sehingga dapat terlihat garis biru pada grafik 11 pltu barru memperlihatkan adanya penurunan gangguan mendekati batas normal

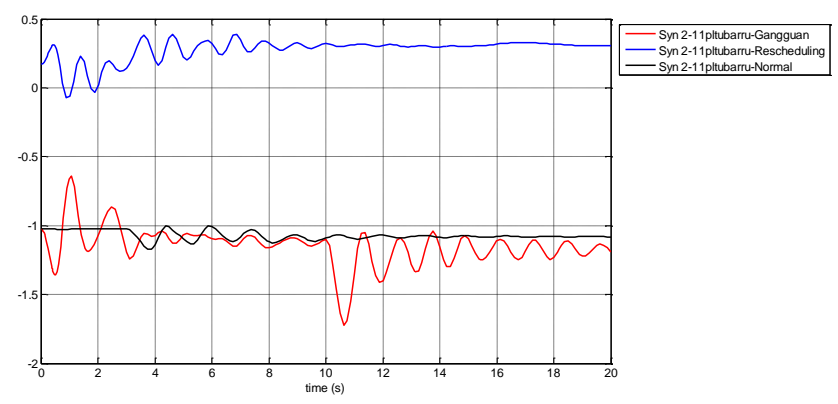

\section{Gambar 6. Kurva gangguan dan rescheduling pada pembangkit 11 PLTU Barru}

\subsection{Pembangkit 39 Palopo}

Pada simulasi percobaan pembangkit 39 palopo, juga terlihat adanya perubahan melaui batas gangguan, perubahan ini berdasarkan pada ketidakseimbangan antara pasokan listrik dan permintaan energi listrik, akibatnya keseimbangan mulai terganggu, untuk itu reschedule ini pada 
simulasi pembangkit gen.39 palopo di tandai garis biru pada grafik sudah memperlihatkan adanya penurunan gangguan mendekati batas normal

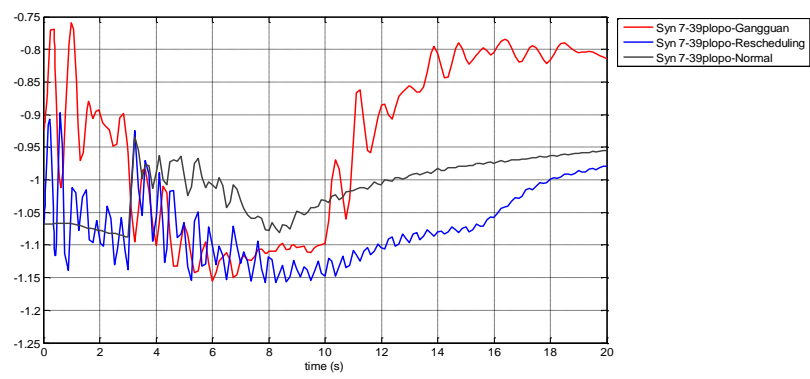

Gambar 7. Kurva gangguan dan rescheduling pada pembangkit 39 Palopo

\section{Kesimpulan}

Berdasarkan dari hasil simulasi pada penelitian ini maka dapat disimpulkan sebagai berikut:

- Hasil simulasi MatLab dengan menggunakan PSAT untuk kodisi kestabilan saat terjadi gangguan pada pembangkit sistem sulselbar melalui pembagian pembebanan pada pembangkit tenaga listrik dengan penjadwalan pembebanan yang akan menyuplai beban, penjadwalan pembebanan / rescheduling dengan rugi saluran transmisi rendah dapat menekan nilai rugi-rugi sistem transmisi.

- Memperbaiki kestabilan sistem saat gangguan dengan menggunakan metode operation rescheduling melalui pembangkit moment inertia pada tiap pembangkit (Pinrang 5.94 $\mathrm{rad} / \mathrm{det}$ ) dibagi dengan jumlah total pembangkit momen inertia (67.66 rad/det) dikalikan dengan jumlah total daya generator (903.48 MW) maka menghasilkan daya recheduling (79.318 Resch) pengganti dari daya generator.

- Efek hasil simulasi MatLab menggunakan PSAT dari operation rescheduling melalui sudut rotor pada pembangkit dipengaruhi pada reference angle semakin besar tegangan pembangkit masukan reference angle maka semakin kecil nilai sudut rotornya dan semakin kecil tegangan pembangkit masukan refence angle maka semakin besar nilai sudut rotor yang dihasilkan.

\section{Referensi}

[1] Sargi, Hadi Sutanto. 2013. Pembebanan penjadwalan menggunakan Fator Penalti pada sistem Transmisi 500 kV jawa-bali Dengan Metode Adaptive Neuro Fuzzy Inference System (ANFIS). Tembalang: Semarang.

[2] Dani, Derwan. 2010. Penjadwalan Proses Sistem Operasi. Yogyakarta: Andi Offset.

[3] Soeprijanto, dkk. 2009. Modified Improved Particle Swarm Optimization for optimal Generator Scheduling. Yogyakarta: SNATI.

[4] Fadli, Muhammad. 2016. Nalisis Kestabilan Tegangan Pada Waktu Beban Puncak (WBP) Dan Luar Waktu Beban Puncak (LWBP) Pada Interkoneksi sulselbar. Makassar: Universitas Hasanuddin.

[5] Rencana Usaha Penyediaan Tenaga (RUPTL) PT PLN (Persero) 2015-2024.

[6] Kundur, P., "Power System Stability and Control", McGraw-Hill, Inc, 1994.

[7] Soeprijanto, Adi. "Desain Kontroller untuk Kestabilan Dinamik Sistem tenaga Listrik". ITS Press, Surabaya, 2012.

[8] Gunadin, I. C., A. Soeprijanto and O. Penangsang (2010). "Real Power Generation Scheduling to Improve Steady State Stability Limit in the Java-Bali 500 kV Interconnection Power System." World Acad. Sci. Eng. Technol 72: 1-5.

[9] Siswanto, Agus. Safrizal, Subiyanta, Errfan. The Voltage Stability of Distribution System using the Distribution Generation Biomass Power Plant, Proceeding of International Conference on Green Technology ISSN:2355-3456 September $3^{\text {rd }}, 2014$, Semarang, Indonesia.

[10] Gunadin, I. C., A. Suprijanto and O. Penangsang (2009). Study on Effect of STATCOM Installation to Improved Voltage Stability in East Indonesia System. Proceeding of National Seminar on Applied Technology, Science, and Art (APTECS), Surabaya.

[11] Kimbark, E. W. (1968). "Power System Stability: SYNCHRONOUS MECHINES." Dover Publications, Inc., New York.

[12] Saadat, H. (1999). "Power System." McGraw-Hill Inc. USA.

[13] Said, S. M., S. Manjang, M. W. Tjaronge and M. A. Thaha (2013). "Electrical Energy Consumption Prediction in South-West Sulawesi Electrical Power System." Editorial Committees.

[14] Dou, X., S. Zhang, L. Chang, Z. Wu, W. Gu, M. Hu and X. Yuan (2017). "An improved CPF for static stability analysis of distribution systems with high DG penetration." International Journal of Electrical Power \& Energy Systems 86: 177-188. 